Cold Spring Harb Perspect Med; doi: 10.1101/cshperspect.a039602

\title{
Corrigendum: Glutamatergic Systems and Memory Mechanisms Underlying Opioid Addiction
}

Jasper A. Heinsbroek, Taco J. De Vries, and Jamie Peters

When this article was first published, the first author's surname was inadvertently misspelled as "Heisbroek." The authors apologize for this error. The correct spelling appears above and in the current version of the article.

Copyright $\odot 2020$ Cold Spring Harbor Laboratory Press; all rights reserved; doi: 10.1101/cshperspect.a040410 Cite this corrigendum as Cold Spring Harb Perspect Med 2020;10:a040410 


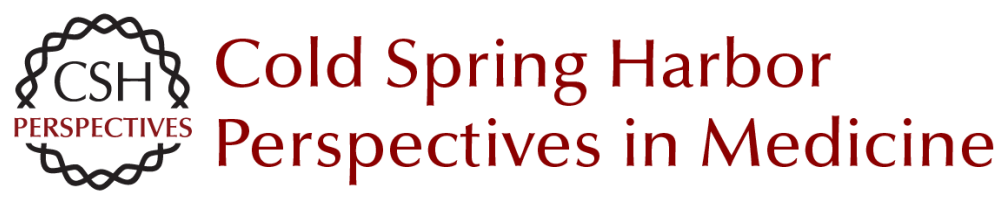

\section{Corrigendum: Glutamatergic Systems and Memory Mechanisms Underlying Opioid Addiction}

Jasper A. Heinsbroek, Taco J. De Vries and Jamie Peters

Cold Spring Harb Perspect Med 2020; doi: 10.1101/cshperspect.a040410

Subject Collection

For additional articles in this collection, see http://perspectivesinmedicine.cshlp.org/cgi/collection/ 